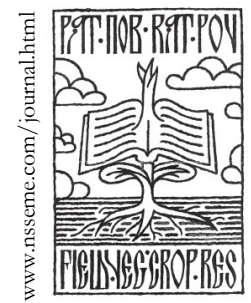

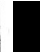

\title{
Soybean Production and a Possibility to Economize the Use of Mineral Fertilizers
}

\author{
Vojin Đukić · Svetlana Balešević Tubić · Zlatica Miladinov · \\ Gordana Dozet · Gorica Cvijanović · Vuk Đorđević · Marija Cvijanović
}

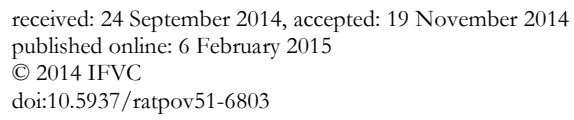

Summary: The trial was carried out in the period 2007-2010 at the experimental field of the Institute of Field and Vegetable Crops in Novi Sad, Serbia. Study was based on applied different fertilizer doses (mineral fertilizers and harvest residues of the previous crop). Trial variants were arranged in a randomized block design and they included: $0 \mathrm{~kg} \mathrm{~N}$ ha-1 without ploughing under crop residues; $0 \mathrm{~kg} \mathrm{~N}$ ha-1 + crop residues; $50 \mathrm{~kg} \mathrm{~N}$ ha-1 + crop residues; $150 \mathrm{~kg} \mathrm{~N}$ ha- $1+$ crop residues; $250 \mathrm{~kg} \mathrm{~N}$ ha- $1+$ crop residues. There were two trial sub-variants with and without soybean seed inoculation within each variant. Seed of soybean cultivar Proteinka (maturity group 0) was inoculated directly before planting, using microbial fertilizer NS-Nitragin containing a mixture of selected highly effective Bradyrbizobium japonicum strains. Seed inoculation produced statistically highly significant yield increases in all four trial years, while the variants with higher doses of nitrogen applied under a preceding crop showed increases in mineral nitrogen uptake from the soil without adequate increases in soybean yield. The application of microbial fertilizers and ploughing under crop residues evidently ensured high yields of soybean, even with reduced doses of nitrogen fertilizer applied to a preceding crop.

Keywords: crop residues, crops, fertilizing, inoculation, mineral nitrogen, soybean products, soybeans, variants, yield

\section{Introduction}

As the world human population continues to increase, the demands placed on agriculture to supply future food and fibre needs will be one of the greatest challenges facing the agricultural community. To meet this challenge, a great deal of effort focusing on the soil biological system and the agro-ecosystem as a whole is needed for better understanding complex processes and interactions governing the stability of agricultural land, large increases of energy inputs, in terms of mechanization, irrigation, fertilizer and pesticide use (Schreiner \& Bethlenfalvay 1995).

The chemical composition of soybean grain determines the economic importance of that crop: about $40 \%$ of proteins which includes all essential amino acids, about $20-25 \%$ of oil with favourable fatty acid composition, and large amounts of minerals and vitamins (Davydenko et al. 2004).

V. Đukić* · S. Balešević Tubić $\cdot$ Z. Miladinov $\cdot$ V. Đorđević Institute of Field and Vegetable Crops, 30 Maksima Gorkog, 21000 Novi Sad, Serbia

e-mail: vojin.djukic@nsseme.com

G. Dozet $\cdot$ G. Cvijanovic

Megatrend University, Faculty for Biofarming, 39 Maršala Tita, 24300 Bačka Topola, Serbia

M. Cvijanović

University of Belgrade, Faculty of Agriculture, 6 Nemanjina, 11080 Zemun, Serbia
To ensure high crop yields, the soil must have good physical properties, such as the structure of aggregates and capillarity (Krmpotic et al. 2003). The ploughing under of soybean crop residues, including nodulated roots, enriches the soil with organic matter and increases its biological value and fertility.

Nitrogen (N) is an important, but frequently a limiting factor to achieving high crop yields. Mineral $\mathrm{N}$ available to plants is subject to depletion, because of its mobility in the soil (leaching and denitrification), or excess due to mineralization of organic matter in the soil (Malešević et al. 2005). A long-term application of mineral fertilizers leads to accumulation of heavy metals in the soil, soil acidification and reduction of humus. Humus depletion leads to a reduced soil fertility and deteriorated structure and water, air and biological regimes of soil (Bajić 2010). Crop production systems may be improved by introducing strategies, which are environmentally friendly. Biological systems such as those involving microbial fertilizer may be used to substitute the expensive chemical fertilizers (Suresh et al. 2010).

Nitrogen fertilization of soybean is quite specific, because soybean is capable of fixing $\mathrm{N}$ and it uses well the residual $\mathrm{N}$ that remains after

Acknowledgements: This study is a part of the project TR 31022 supported by the Ministry of Education, Science and Technological Development of the Republic of Serbia. 
the preceding crop. The bacteria Bradyrbizobium japonicum, Bradyrbizobium elkani and Sinorbizobium fredi live in symbiosis with soybean, forming nodules on soybean roots, which annually fix up to $180 \mathrm{~kg} \mathrm{~N} \mathrm{ha-1}$. These bacteria also produce growth substances such as indoles and gibberellins, which stimulate the growth of host plants. Soybean plants fix $50-70 \%$ of the total amount of $\mathrm{N}$ needed to produce high yields (Krmpotić et al. 2003). Soybean plants respond specifically to the increased content of available $\mathrm{N}$ in the soil, by discontinuing $\mathrm{N}$ fixation and reducing grain yield. Correct choice of appropriate $\mathrm{N}$ doses depends on soil type, nutrient status, weather conditions and many other factors that directly or indirectly affect the yield (Đukić et al. 2010). The need to use renewable forms of energy and reduce fertilization costs has revived the use of organic fertilizers, green manure, and microbial fertilizers worldwide (Cvijanović et al. 2008). The importance of soybean and $\mathrm{N}$-fixing bacteria can be seen from the fact that the production of $\mathrm{N}$ fertilizers accounts for about $25 \%$ of the total energy spent for agricultural production in the developed countries (Adamen et al. 2003). The objective of this study was to determine the effect of soybean fertilization, including the different $\mathrm{N}$ doses added to the preceding crop, ploughing under of crop residues and use of microbial fertilizer, in achieving high and stable soybean yield, while economizing with the application of mineral $\mathrm{N}$ fertilizers within an environmentally safe production.

\section{Materials and Methods}

A four-year field trial was set up at the experimental field of Institute of Field and Vegetable Crops, Novi Sad, Serbia $\left(45^{\circ} 20^{\prime} 0^{\prime \prime}\right.$ North latitude and $19^{\circ} 51^{\prime} 0^{\prime \prime}$ Eastern longitude, $72-80 \mathrm{~m}$ a.s.l.). The soil is carbonate chernozem with the following characteristics: the $\mathrm{pH}$ value was $7,1.95 \%$ of $\mathrm{CaCO}_{3}, 2.63 \%$ of humus, $11.2 \mathrm{mg}$ of $\mathrm{P}_{2} \mathrm{O}_{5} 100 \mathrm{~g}^{-1}$ of soil, and $20.5 \mathrm{mg}$ of $\mathrm{K}_{2} \mathrm{O}$ $100 \mathrm{~g}^{-1}$ of soil. The trial included a three-crop rotation (corn - soybean - wheat) in four replications. Variants were arranged in a randomized block design. The variants included $0 \mathrm{~kg} \mathrm{~N}^{-1}$ without ploughing under crop residues, $0 \mathrm{~kg} \mathrm{~N} \mathrm{ha-1} \mathrm{+} \mathrm{crop} \mathrm{residues,} 50 \mathrm{~kg} \mathrm{~N} \mathrm{ha-1}$
+ crop residues, $150 \mathrm{~kg} \mathrm{~N} \mathrm{ha}^{-1}+$ crop residues, and 250 $\mathrm{kg} \mathrm{N} \mathrm{ha-1}+$ crop residues.

There were two sub-variants with and without soybean seed inoculation within each variant. Seed of soybean cultivar Proteinka (maturity group 0) was inoculated directly before planting, using microbial fertilizer NS-Nitragin containing a mixture of selected highly effective Bradyrbizobium japonicum strains.

In the variants with ploughing under crop residues, $50 \mathrm{~kg}$ of $\mathrm{N} \mathrm{ha}^{-1}$ (KAN 27\%) were applied after wheat harvesting in order to prevent $\mathrm{N}$ depression. All variants in the trial received equal amounts of phosphorus (P) and potassium (K) fertilizers (80 kg ha-1 of each, $\mathrm{P}_{2} \mathrm{O}_{5}$ and $\mathrm{K}_{2} \mathrm{O}$ ). Superphosphate $(18 \%)$, potassium salt $(40 \%)$ and half of the total amount of $\mathrm{N}$ (KAN 27\%) were incorporated into the soil before the primary tillage for maize and the remaining amount of nitrogen (KAN 27\%), depending on variant, was applied before maize seedbed preparation. Soybean was not fertilized before primary tillage or seedbed preparation. Soybean received conventional cultivation practices in all four years.

The trial units were $5 \mathrm{~m}$ long and $3 \mathrm{~m}$ wide (15 $\mathrm{m}^{2}$ ). The entire trial consisted of 40 experimental plots, i.e. 10 variants in four replications. The plant density was $50 \times 3.5 \mathrm{~cm}(571,430$ plants per ha). One border row in each experimental plot was considered as isolation and the four inside rows were taken for the analysis.

Prior to soybean planting and at the stage of technological maturity, soil samples were taken from $30 \mathrm{~cm}$ layers to a depth of $90 \mathrm{~cm}$ for determination of mineral $\mathrm{N}$ content. Consumption of mineral $\mathrm{N}$ from the soil was calculated based on the difference in the quantities of mineral $\mathrm{N}$ in spring and autumn, the obtained yield and the average mineralization for the conditions of the Vojvodina Province of Serbia. After harvesting the experimental plots, grain weight and moisture content were measured and grain yield was calculated $\left(\mathrm{kg} \mathrm{ha}^{-1}\right)$, based on $14 \%$ moisture content.

The obtained results were statistically analysed using a three-factorial analysis of variance (software MSTAT-C), and significance of differences between treatments was tested with the LSD test.

Table 1 . Weather conditions in the study years

\begin{tabular}{|c|c|c|c|c|c|c|c|c|c|c|}
\hline \multirow{2}{*}{ Month } & \multicolumn{4}{|c|}{ Mean monthly temperature $\left({ }^{\circ} \mathrm{C}\right)$} & \multirow{2}{*}{$\begin{array}{c}\text { Average } \\
1966- \\
2006\end{array}$} & \multicolumn{4}{|c|}{ Precipitation (mm) } & \multirow{2}{*}{$\begin{array}{c}\text { Average } \\
1966- \\
2006\end{array}$} \\
\hline & 2007 & 2008 & 2009 & 2010 & & 2007 & 2008 & 2009 & 2010 & \\
\hline IV & 13.4 & 13.0 & 14.6 & 12.3 & 11.4 & 0.0 & 21.9 & 3.6 & 63.7 & 48.8 \\
\hline $\mathrm{V}$ & 18.5 & 18.4 & 18.6 & 16.9 & 16.8 & 98.6 & 46.2 & 50.4 & 113.7 & 59.5 \\
\hline VI & 22.1 & 21.8 & 19.6 & 20.2 & 19.9 & 71.1 & 115.9 & 127.2 & 171.8 & 85.9 \\
\hline VII & 23.3 & 21.7 & 22.8 & 23.1 & 21.4 & 38.8 & 41.6 & 58.1 & 99.0 & 68.2 \\
\hline VIII & 22.7 & 22.2 & 22.9 & 21.9 & 21.0 & 79.6 & 14.0 & 19.1 & 167.7 & 56.9 \\
\hline IX & 14.6 & 15.2 & 19.2 & 16.1 & 16.8 & 78.8 & 93.6 & 13.1 & 67.7 & 45.1 \\
\hline Average/total & 19.1 & 18.7 & 19.6 & 18.4 & 17.9 & 366.9 & 333.2 & 271.5 & 683.6 & 364.4 \\
\hline
\end{tabular}




\section{Results and Discussion}

The highest average soybean yield $\left(4,598 \mathrm{~kg} \mathrm{ha}^{-1}\right)$ was achieved in 2010, in which the highest sum of precipitation and a favourable distribution during the growing season were recorded. In an unfavourable year, such as 2007 , the soybean yield was the lowest $\left(3,443 \mathrm{~kg} \mathrm{ha}^{-1}\right)$. In this year, there was no precipitation in April, which negatively affected soybean emergence and reduced the yield. Extremely high temperatures and drought that occurred in July caused pod drop in soybean plants. The growing season of 2008 was slightly better concerning the distribution of precipitation and the average daily temperature than the previous year. Accordingly, the average yield was slightly higher $\left(3,724 \mathrm{~kg} \mathrm{ha}^{-1}\right)$. In the growing season of 2009 temperatures were higher than the long-term average and the precipitation sum was less compared to long-term average, with uneven distribution, and the soybean yield was $3,473 \mathrm{~kg} \mathrm{ha}^{-1}$.

The microbial fertilizer application significantly increased soybean yield in all studied years (Figure 1) except in 2007, when the adverse conditions early in the season, as well as high temperatures and precipitation deficit in July, reduced the inoculation rate and negatively affected yield in both treatments (with and without inoculation).

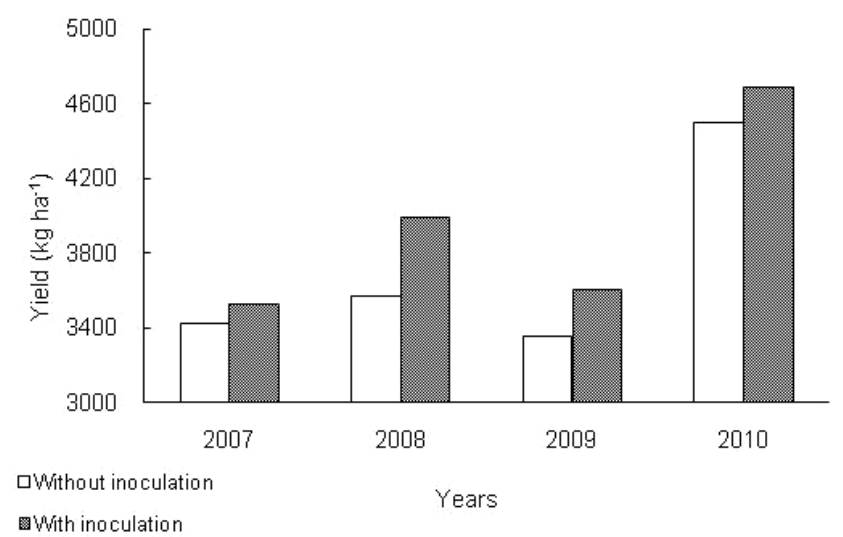

Figure 1. Effects of microbiological fertilizer on soybean yield

Soybean yield increase ranged from $3 \%$ to $12 \%$ in the variants with applied inoculation, depending on the year and weather conditions during the growing season. In the unfavourable 2007, the maximum soybean yield was achieved with $150 \mathrm{~kg} \mathrm{~N}^{-1}$ added under the preceding crop (Tab. 2), while in the other studied years, maximum yields were recorded with 50 $\mathrm{kg} \mathrm{N} \mathrm{ha-1}$ added to the preceding crop and the application of the microbial fertilizer.

Other authors also emphasized that the use of microbial fertilizer led to increased yield and reduced application of $\mathrm{N}$ fertilizer, and the intensity of the effects depended on growing conditions. When agrometeorological conditions were less favourable for plant production, the effect of inoculation was significantly higher when 90 and $120 \mathrm{~kg} \mathrm{~N} \mathrm{ha-1}$ were applied (Cvijanović et al. 2008). Mineral N doses over $120 \mathrm{~kg} \mathrm{ha}^{-1}$ could not be justified by the obtained yield increases. In favourable year soybean seed inoculation increased the yield by $25.19 \%$ compared to non-inoculated plants, and in less favourable year the yield increase was $15.3 \%$ (Mrkovački et al. 2002). Inoculation is a low-cost way to ensure good nodulation with proper strain of $\mathrm{N}$ fixing bacteria for increased yield in an environmentally safe manner.

Table 2. Effect of nitrogen fertilizer doses on soybean yield

\begin{tabular}{lccccc}
\hline Variant & \multicolumn{3}{c}{ Soybean yield $\left(\mathrm{kg} \mathrm{ha}^{-1}\right)$} & \multicolumn{2}{c}{$\begin{array}{c}\text { Average } \\
\left(\mathrm{kg} \mathrm{ha}^{-1}\right)\end{array}$} \\
\hline 0 & 2007 & 2008 & 2009 & 2010 & $3,655.5$ \\
$0+\mathrm{CR}$ & $3,300.9$ & $3,490.1$ & $3,368.6$ & $4,462.4$ & $3,835.3$ \\
$50+\mathrm{CR}$ & $3,271.8$ & $3,853.5$ & $3,548.6$ & $4,667.2$ & $3,957.1$ \\
$100+\mathrm{CR}$ & $3,390.3$ & $4,077.9$ & $3,600.8$ & $4,759.4$ & $3,897.5$ \\
$150+\mathrm{CR}$ & $3,634.7$ & $3,713.9$ & $3,609.5$ & $4,631.9$ & $3,700.8$ \\
\hline
\end{tabular}

$\mathrm{LSD}_{0.05}=243$

CR-crop residues 
On average for all trial years (Fig. 2), the variants in which 50 and $150 \mathrm{~kg} \mathrm{~N} \mathrm{ha}^{-1}$ were applied under the preceding crop, with ploughing under crop residues, significantly higher soybean yield was achieved (3,957 and $3,897.5 \mathrm{~kg} \mathrm{ha}^{-1}$, respectively) than the variant without $\mathrm{N}$ and crop residues $\left(3,655.5 \mathrm{~kg} \mathrm{ha}^{-1}\right)$. The combination of crop residues and mineral fertilizer evidently stimulated microbial processes in the soil. Depending on the type of soil and climate conditions, microorganisms immobilize 7 to $15 \mathrm{~kg} \mathrm{~N}^{-1}$ during straw degradation, which may explain the positive impact of ploughing under crop residues on the microorganisms' abundance and activity (Milošević et al. 1997).

In the variants without $\mathrm{N}$ application as well as in those in which nitrogen was applied under the preceding crop, seed inoculation increased the soybean yield $(3,933$ $\mathrm{kg} \mathrm{ha-1}$ ) in relation to the variants without inoculation $\left(3,691 \mathrm{~kg} \mathrm{ha}^{-1}\right)$. The yield increasing was statistically significant for all studied years. These results are in agreement with the findings of many other authors who studied the impact of microbial fertilizers application in plant production (Đukić et al. 2008, Milić et al. 2003).

Mineral $\mathrm{N}$ uptake from the soil was the highest in the variant with $250 \mathrm{~kg} \mathrm{~N}$ ha-1 applied under the preceding crop, while the soybean yield was lower than in the other variants (Figure 2). The amount of mineral $\mathrm{N}$ in the soil is highly variable and it depends on a number of factors: soil fertility and biological value, ploughing under crop residues, organic matter input, fertilization of the preceding crop, methods of land use and climatic factors (Starčević et al. 2003).

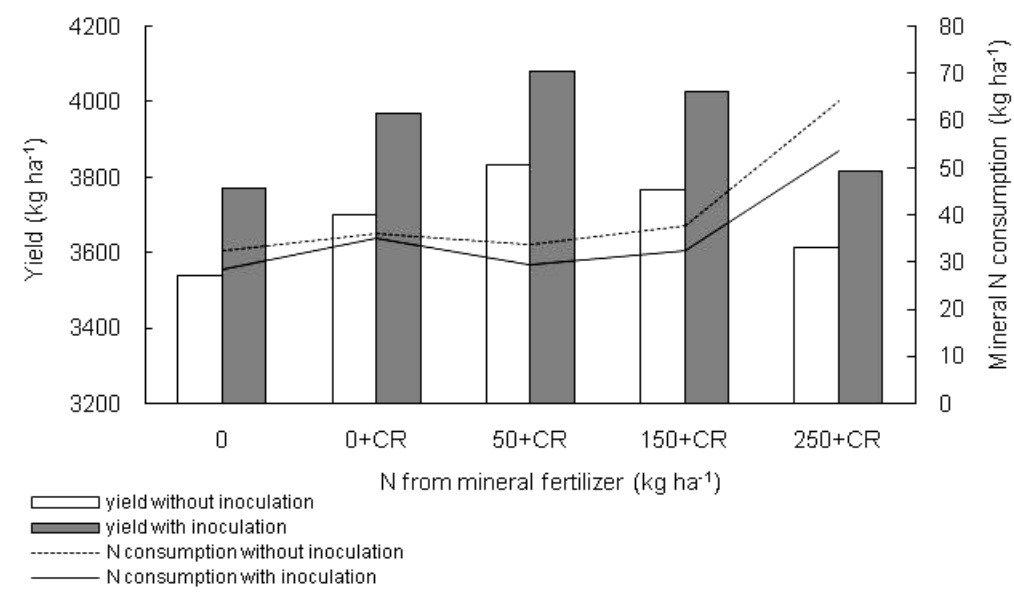

Figure 2. Soybean yield and mineral $\mathrm{N}$ uptake from the soil $\left(\mathrm{kg} \mathrm{ha}^{-1}\right)$

In the variants with application of the microbial fertilizer, a lower uptake of mineral $\mathrm{N}$ from the soil was recorded, as well as significant increases in soybean yield, as compared to the variants without the microbial fertilizer (Dozet et al. 2013). This indicates that the inoculated plants preferred atmospheric $\mathrm{N}$, which brought significant yield increases compared to the soil N. In soybean production, the use of microbial fertilizer allows replacement of $\mathrm{N}$ from mineral fertilizer with biological $\mathrm{N}$, with both economic and ecological benefits. The application of microorganisms reduces the use of mineral $\mathrm{N}$ fertilizers; it does not pollute the soil, improves soil structure, increases organic matter content and positively affects the physical properties of soil (Milić et al. 2003).

In the four-year period, the highest soybean yield was achieved in the variants with $50 \mathrm{~kg} \mathrm{~N} \mathrm{ha}^{-1}$, both with and without inoculation. The increased doses of
$\mathrm{N}$ applied under the preceding crop led to a reduction in soybean yield and significant increases in the uptake of mineral $\mathrm{N}$ from the soil, i.e. a reduced use of atmospheric $\mathrm{N}$. If the soil profile of $0-90 \mathrm{~cm}$ contains $65 \mathrm{~kg} \mathrm{ha}^{-1}$ or more mineral $\mathrm{N}$ prior to soybean planting, additional $\mathrm{N}$ fertilizer is not needed for high soybean yield (Dozet 2009). Application of the higher $\mathrm{N}$ doses (100 and $150 \mathrm{~kg} \mathrm{ha}^{-1}$ ) increased nitrate concentration in soybean seed, lowered organic matter and total soil $\mathrm{N}$. Combination of low doses of $\mathrm{N}$ application (25 and $50 \mathrm{~kg} \mathrm{ha}^{-1}$ ) and rhizobial inoculation did not significantly change $\mathrm{N}$ total of top soil. Application of about $50 \mathrm{~kg} \mathrm{~N} \mathrm{ha-1}$ together with rhizobial inoculation seemed to be an appropriate cultivation practice for soybean cultivated in soil in the Mekong Delta (Diep et al. 2002). If a field has a history of soybean with good nodulation, supplemental $\mathrm{N}$ would probably not be required even if the soil $\mathrm{N}$ levels were low (Frazen 1999). 


\section{Conclusions}

Soybean seed inoculation before planting was found to be an acceptable cultivation practice. It tends to increase soybean yield, regardless of the amount of $\mathrm{N}$ applied under the preceding crop, and it enhances positive effects of ploughing under crop residues. The $\mathrm{N}$ amount of $50 \mathrm{~kg} \mathrm{ha}^{-1}$ applied under the preceding crop increased the soybean yield while the amount of $250 \mathrm{~kg} \mathrm{ha}{ }^{-1}$ reduced the yield. The application of increased amounts of $\mathrm{N}$ fertilizer under the preceding crop increased the uptake of mineral $\mathrm{N}$ from the soil, without a corresponding increase in the soybean yield. Use of microbial fertilizer in soybean production, ploughing under crop residues and the utilization of residual $\mathrm{N}$ from the soil are important practices that relieve the issue of land preservation while maintaining the economic effects of soybean production.

\section{References}

Adamen, F. F., Sichkar, V. I., \& Pysmenov, V. N. (2003). Soybeans: industrial processing, feed additives, food (In Russian) 2nd ed., NoraPrint Publishers, Kyiv, 476.

Bajić, N. (2010). Similarities and differences between conventional and organic production. 1st Intl. Conference of healthy food, ecology and organic production of food, BioPlanetBook, Zlatibor, Serbia, 24 31.

Cvijanović, G., Subić, J., \& Dozet, G. (2008). The significance of nitrogen -fixer as a biofertilizer in organic production. International Symposium on New Researches in Biotechnology, Ministry of Education and Research, University of Agronomical Sciences and Veterinary Medicine Bucharest, Special Volume, Serie F, Bucharest, November 20-21, 2008, pp. 574-582.

Davydenko, O. G., Goloenko, D. V., \& Rosenzweig V. E. (2004). Soybean for temperate climate (In Belarusian), Tehnologija Minsk, Belarus, 173.

Diep, C. N., Dang, V. H., Ngau, N. V., Son, M. T., \& Duong, T. P. (2002). Effect of rhizobial inoculation and inorganic nitrogen fertiliser on vegetable soybean (Glycine $\max$ (L.) Merr.) cultivated on alluvial soil of Canto provanc4e (Mecong Delta) using ${ }^{15} \mathrm{~N}$ isotope dilution technique. In: D Herridge (ed.), Inoculants and nitrogen fixation of legumes in Vietnam. ACIAR Proceedings: pp.81-85.

Dozet, G. (2009). Uticaj dubrenja predkulture azotom i primene Co i Mo na prinos $i$ osobine zrna soje. Doctoral dissertation. Megatrend University, Belgrade, 174.

Dozet, G., Cvijanović, G., \& Đukić, V. (2013). Changes in the Technology of Soybean Production, Sustainable Technologies, Policies, and Constraints in the Green Economy, Advances in Environmental Engineering and Green Technologies (AEEGT) Book Series, IGI Global Book USA, pp. 1-22.

Đukić, V., Balešević-Tubić, S., Dozet, G., Valan, D., Pajić, V., \& Đorđević, V. (2008). Uticaj đubrenja na sadržaj ulja u zrnu soje. Zbornik radova 49. Savetovanje industrije ulja, Herceg Novi, Crna Gora, 95-100.

Đukić,V., Đorđević, V., Popović, V., Balešević-Tubić, S., Petrović, K., Jakšić, S., \& Dozet, G. (2010). Effect of nitrogen and Nitragin application on soybean yield and protein content. Ratar. Pourt. 47: 187-192.

Frazen, D. W. (1999). Soybean soil fertility. Educational material. North Dacota State University, SF-116.

Krmpotić, T., Musanić, G., \& Hojka, Z. (2003). Pedologija sa agrohemijom. Megatrend University, Belgrade, 53-73.

Malešević, M., Crnobarac, J., \& Kastori, R. (2005). Use of nitrogen fertilizers and their effect on yield and product quality. In: R Kastori (ed.) Nitrogen. Agrochemical, cultural practice, physiological and ecological aspects. Institute of Field and Vegetable Crops, Novi Sad, pp. 231-261.

Milić, V., Hrustić, M., Vasić, M., Starčević, Lj., \& Marinković, J. (2003). Use of microbiological fertilizers in bean, soybean and maize production. Zbornik radova Instituta za ratarstvo $i$ povrtarstvo Novi Sad 38: 259-270.

Milošević, N., Govedarica, M., \& Jarak, M. (1997). Microbial activity - an important parameter indetermining soil fertility. Zbornik radova Instituta za ratarstvo i pourtarstvo Novi Sad 29: 19-97.

Mrkovački, N., Milić, V., \& Belić, M. (2002). Application of Nitragin in soil where soybean was not grown. Zbornik radova Instituta za ratarstvo i pourtarstvo Novi Sad 36: 139-145.

Schreiner, R. P., \& Bethlenfalvay, G. J. (1995). Mycorrhizal interactions in sustainable agriculture. Critical Reviews in Biotechnology, 15(3-4): 271-285.

Starčević, Lj., Latković, D., \& Marinković, B. (2003). Mineral nitrogen in the soil and its effect on corn yield. Annales UMCS, Sec. E, 58: 177-184.

Suresh, A., Pallavi, A. P., Srinivas, P., Kumar, P. V., Chandra J. S., \& Reddy R. S. (2010). Plant growth promoting activities of fluorescent pseudomonads associated with some crop plants. Afr. J. Microbiol. Res., 4(14): 1491-1494.

\section{Proizvodnja soje i mogućnost ekonomične upotrebe mineralnih đubriva}

Vojin Đukić · Svetlana Balešević Tubić · Zlatica Miladinov · Gordana Dozet · Gorica Cvijanović · Vuk Đorđević · Marija Cvijanović

Sažetak: Eksperiment je izveden u periodu 2007-2010. godine na oglednom polju Instituta za ratarstvo i povrtarstvo, Novi Sad. Studija je zasnovana na primenjenim različitim varijantama đubriva (mineralna đubriva $i$ biljni ostaci prethodnog useva). Varijante ogleda su raspoređene po slučajnom blok sistemu: $0 \mathrm{~kg} \mathrm{~N}^{\mathrm{h}} \mathrm{Na}^{-1}$ bez

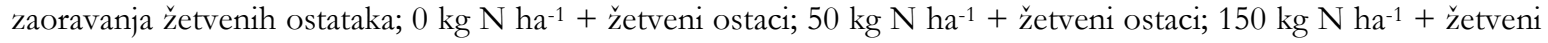
ostaci; $250 \mathrm{~kg} \mathrm{~N} \mathrm{ha-1}+$ žetveni ostaci. U okviru svake varijante postojale su dve pod-varijante sa i bez inokulacije semena soje. Seme soje sorte Proteinka (0 grupa zrenja) je neposredno pre setve inokulisano mikrobiološkim đubrivom NS-Nitragin koje sadrži mešavinu odabranih visoko efikasnih sojeva bakterija Bradyrbizobium japonicum. Inokulacija semena dovela je do statistički veoma značajnog povećanja prinosa u sve četiri godine istraživanja, dok su varijante sa visokim dozama azota primenjene pod predusev dovele do povećanja usvajanja mineralnog azota iz zemljišta bez odgovarajućeg povećanja prinosa soje. Primena mikrobioloških đubriva i zaoravanje biljnih ostataka može da obezbedi visoke prinose soje, čak i pri smanjenim dozama azotnih đubriva koje su primenjene u prethodnom usevu.

Ključne reči: đubrenje, inokulacija, mineralni azot, prinos, soja, sojini proizvodi, usevi, varijante, žetveni ostaci 